表面と真空 Vol. 64, No. 4, pp. 191-192, 2021 https://doi.org/10.1380/vss.64.191

開催報告

2020 年度オンライン真空講習会入門講座, オンライン真空講習会開催報告

間瀬一彦 ${ }^{1, *}$ ・関口 敦 ${ }^{2}$

1 高エネルギー加速器研究機構物質構造科学研究所 函 305-0801 茨城県つくば市大穂 1-1

2 工学院大学 教育支援機構

凿 192-0015 東京都八王子市中野町 2665-1

(2021 年 1 月 24 日受理)

\section{Report on 2020 Vacuum Online Course and Introductory Vacuum Online Course}

Kazuhiko MAsE $^{1, *}$ and Atsushi SeKIGUCHI ${ }^{2}$

${ }^{1}$ IMSS, KEK, 1-1 Oho, Tsukuba, Ibaraki 305-0801 ${ }^{2}$ KOGAKUIN Univ.,

2665-1 Nakano, Hachioji, Tokyo 192-0015

(Received January 24, 2021)

\section{1.は じめに}

日本表面真空学会主催による 2020 年度オンライン真 空講習会入門講座を 10 月 19 日（月）12 時〜 30日（金） 12 時に, オンライン真空講習会を 2020 年 11 月 2 日 (月) 12 時〜30日（月）12 時にそれぞれ開催しました。 当初は第 60 回となる真空夏季大学 ${ }^{1 \sim 3)} 2020$ 年 8 月 25 日 (火)〜28日 (金) につま恋リゾート彩の郷にて開 催する予定でしたが，新型コロナウィルス（COVID-19） 感染拡大防止のため, 中止せざるを得なくなりました。 そこで 2020 年度は, 真空夏季大学の代わりとして, オ ンライン真空講習会を開催し，その前段階としてオンラ イン真空講習会入門講座を開催しました。

\section{2. オンライン真空講習会入門講座}

オンライン真空講習会入門講座の目標はオンライン真 空講習会を受講するために必要な最低限の知識を習得す ることです。前回までの真空夏季大学開催後のアンケー トで，本講座受講前に入門講座受講希望がありました。 このため, 真空関連業務を始めて 1 年以内の方, 初歩的 な真空技術を復習したい方, を対象として別枠で入門講 座を開催しました。数式は極力使わず, 図などを利用し

\footnotetext{
*E-mail : mase@sssj.org
}

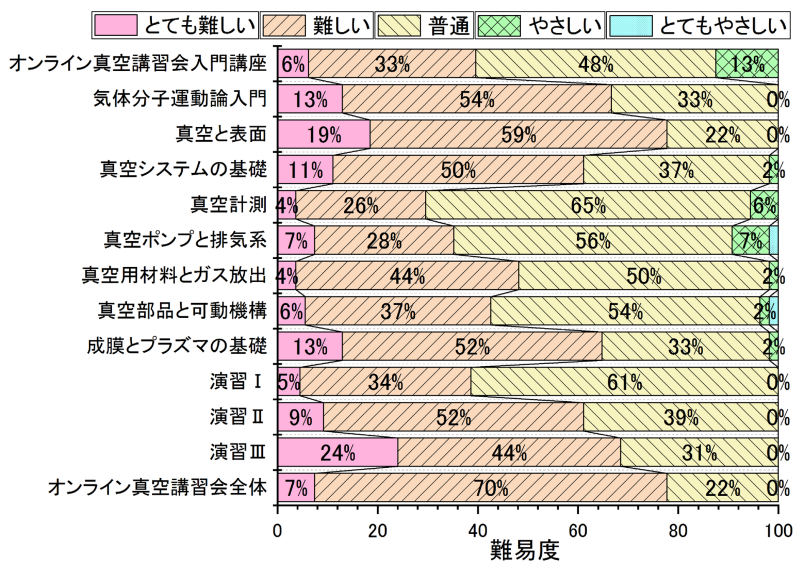

Fig. 1. (color online). Results of a survey on the level of difficulty. Number of answers for Vacuum Online Course and Introductory Vacuum Online Course are 48 and 54, respectively.

て真空技術の基礎, 真空計, 真空ポンプ, 真空用材料, 真空部品などについて解説する動画を作成し, ラーニン グシステム上でオンデマンド方式にて受講できるように しました。受講者数は 57 名でした。

アンケート結果によると難易度は「普通」, 内容は 「満足」, 時間は「普通」, 説明は「普通」, テキストは 「わかりやすい」という回答がそれぞれ最多で（Fig. 1, Fig. 2 参照), 感想, コメントは「勉強になった」,「役 に立った」が多数でした。この結果から今回, 新しい試 みである入門講座の開講の目的は果たせたと思われま す。一方で，「図の説明をきちんとしてほしい」，「計算 式の記号をその場で定義してほしい」,「かみ砕いて分か りやすく説明して欲しい」，などの要望もありました。 こうした意見を参考にして，今後のオンライン講習会入 門講座の改善を図りたいと思います。

\section{3. オンライン真空講習会}

オンライン真空講習会の目標は真空夏季大学と同様 に, 受講者が真空技術の基礎を理解し, 装置を正しく運 用し，さらには新たな技術の展開に対応できる能力を育 むことです。このため内容は, 気体分子運動論入門, 真 空と表面, 真空システムの基碟, 真空計測, 真空ポンプ と排気系, 真空用材料とガス放出, 真空部品と可動機 構, 成膜とプラズマの基礎のオンデマンド講義と演習 I, 演習 II, 演習 III の演習問題, オンラインによる達成度 テストにて構成しました。受講者数は, 昨年度の真空夏 季大学受講者数（97 名）より若干多い99名でした。 


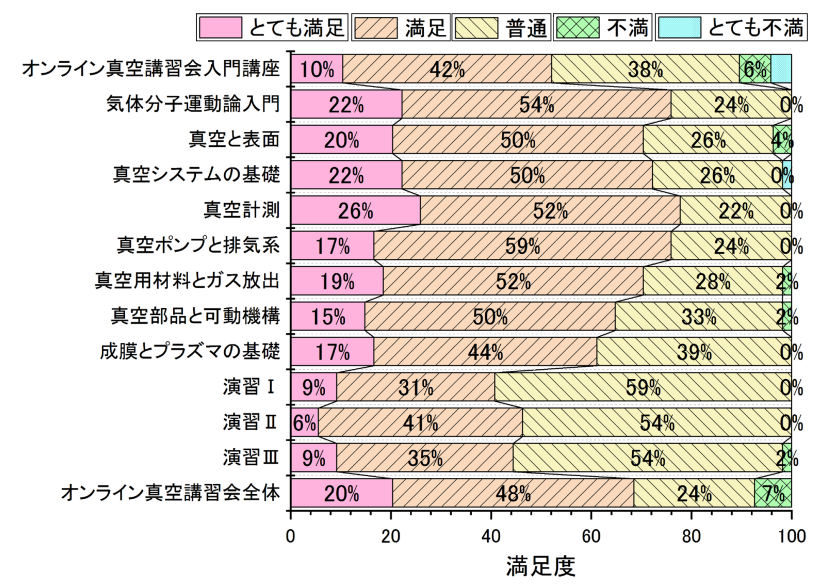

Fig. 2. (color online). Results of a survey on the level of satisfaction. Number of answers for Vacuum Online Course and Introductory Vacuum Online Course are 48 and 54, respectively.

今回，新しくオンライン講習会を開催するにあたりシ ステム上のトラブルが発生してしまいました。すなわち 開講当初, 閲覧集中によって一部の受講者はオンデマン ド形式講義資料が閲覧できませんでした。このため，オ ンデマンドにもかかわらず, 受講者の皆様にアクセス分 散をお願いする結果となってしまいました。

難易度に関するアンケート結果のグラフを Fig. 1 に, 満足度に関するアンケート結果のグラフを Fig. 2 にそれ ぞれ示します。難易度は「難しい」,「普通」という回答 が多く, 満足度は「満足」, 「普通」という回答が多いと いう結果でした。テキストの全体的な内容は, 「適当で ある」, 罒のわかりやすさは「普通」, 式の導入, 導出は 「普通」, パワーポイント縮小版は「役立つ」, 演習に関
する要望は「現状のままでよい」，ラーニングシステム の使いやすさは「普通」という回答がそれぞれ最多でし た。また, 感想, コメントでは「勉強になった」,「役に 立った」,「オンデマンド形式で勉強しやすかった」が多 数でした。一方で，「接続不良があったのは残念」，「公 開期間を長くしてほしい」,「一部音声が聞こえづらい講 座があった」などのコメントもありました。こうした意 見を参考にして, 今後のオンライン真空講習会を改善し たいと思います。

\section{4. お わに}

今回は従来の真空夏季大学の講義内容をオンラインで 行うという初めての試みで, 不備な点がいろいろあった と思います。また，事務局と講師，教育・育成委員会の 方々には多大な負担をかけてしまいました。しかしなが ら，アンケート回答を見ると好意的なコメントが多く， 開催してよかったと思います。本原稿執筆時点（2021 年 1 月 12 日）でも新型コロナウィルス感染症の流行に は収束の気配が見られないので, 今後も真空関連企業の 要望に応えてょりよいオンライン講習会を企画したいと 考えております。最後に, オンライン真空講習会入門講 座，オンライン真空講習会の開催に尽力してくださった 事務局の方々, 講師の方々, 教育 - 育成委員会の方々, 宣伝を行ってくださった日本真空工業会の皆様に感謝い たします。

\section{文献}

1) 山川紘一郎 : 表面と真空 62, 734 (2019).

2) 小倉正平 : 表面と真空 61, 743 (2018).

3) 未次祐介 : 表面と真空 61, 94 (2018). 